\title{
Eco-panels Based on Wastes from Urban Trees and Castor Oil Polyurethane Resin
}

\author{
Marilia da Silva Be rtolini ${ }^{1, *}$, Maria Fátima do Nascimento ${ }^{1}$, Karen Aneris Blecha ${ }^{2}$, \\ Francis co Antonio Rocco Lahr ${ }^{1}$
}

\author{
${ }^{1}$ Wood and Timber Structures Laboratory, Structural Engineering Department, University of Sao Paulo (EESC/USP), São Car los, 13566-590, \\ Brazil \\ ${ }^{2}$ State School "Professor Joaquim de Toledo Camargo", Itirapina, 13530-000, Brazil
}

\begin{abstract}
Urban trees have aesthetic functions and mitigate high temperatures, however their maintenance requires constant pruning. This work aimed to apply the tailings resulting fro $m$ tree management in partic leboard production. Partic les fro m urban tree pruning of Jatobá, Canelinha and mixture of these species were used, in addition to castor oil resin as adhesive. Particleboard was evaluated according to NBR 14810:3 and results compared with the main standards. Panels presented satisfactory values for water absorption and thickness swelling. For mechanical properties, partic leboards made from Jatobá showed better results. Thus, it's possible employ residues from pruning high density urban tree in particleboard.
\end{abstract}

Keywords Particleboards, Wood Pruned Residues, Adhesive From Biomass

\section{Introduction}

Brazilian cities have, in their urban landscape, a relatively large quantity of trees, planted in general not only for aes thetic purposes but also to alleviate the high temperatures occurring during summer and spring in a wide extension on the country.

Most species needs periodic branches pruning, primarily to: fulfill the essences characteristic requirements with regard to their development and longevity and; - ensure the safety of electric power trans mission wires.

The amount of waste generated by tree blanches pruning can reach significant values. Although there is no bibliographic record this sense, observations made in this work turned possible quantify in approximately $0.01 \mathrm{~m}^{3}$ per capita per year. Regarding the city of São Carlos, State of São Paulo, Brazil, in 2010 its population exceeded 200,000 habitants and the volume generated could reach $2,000 \mathrm{~m}^{3} /$ year.

These residues are usually deposited in the areas of urban waste disposal. While do not constitute serious threats to environmental damage (due to the ease of decomposition), such waste should be studied to establish the potential for its use in applications that add value to the raw material and come to benefit the community.

Production of particleboard based on lignocellulosic

* Corresponding author:

marilia.bertolini@usp.br (Marilia da Silva Bertolini)

Published online at http://journal.sapub.org/ijaf

Copyright (C) 2013 Scientific \& Academic Publishing. All Rights Reserved residues is characterized as a sustainable alternative, bringing benefits not only to chain-generating waste, but to consumer market of this product.

In this sense, the present study aimed to evaluate the technical viability of using waste of urban tree pruning, city of São Carlos, in particleboards production.

\subsection{Liter ature Review}

Trees in urban areas have aesthetic functions and mitigate high temperatures, however their maintenance requires constant pruning, resulting in waste like leaves and twigs.

Some studies have been developed to waste tree volume evaluation in order to guide for appropriate applications. Sajdak and Velázquez-Martí[1] quantified the biomass resulting from annual pruning of urban trees of the species Sophora japonica, core fairly employed for this purpose throughout Europe. Authors obtained up to $18 \mathrm{~kg}$ of dry biomass per tree, based on the volume of branches (no leaves), moisture about $45 \%$. It was also determined a significant association between the amount of biomass and tree diameter, by linear regression, $\mathrm{R}^{2}=0.60$. Thus, authors could estimate the waste tree volume, for example, to applications such as solid fuel (conservation of energy)[1].

Although designed to achieve energy, this biomass has great potential to panel manufacturing. Particleboards (Medium Density Particleboard) stand out among other wood base products, with significant production worldwide, about 90 million $\mathrm{m}^{3}$ in 2009[2].

Peredo[3] produced particleboards employing wood $(83 \%)$, skin $(14 \%)$ and leaves $(3 \%)$, comparing them to panels of the same specie (Pinus silvestris), 100\% wood 
particles, using phenol formaldehyde, is ocyanate and mixing melamine, urea and phenol formaldehyde as adhesives. Values of strength in bending of panels with biomass exceeded the requirement set by DIN 68 763, reaching values greater than $25 \mathrm{MPa}$.

Iwakiri et al.[4] used waste slabs of Eucalyptus saligna, Eucalyptus citriodora, Eucalyptus pilularis andureaformaldehyde resin to manufacture such panels. Bending and internal bond properties obtained with residues of Eucalyptus saligna and $12 \%$ of adhesive were greater than requirements of Code CS 236-66 (1968).

Gupta[5] used only Pinus bark to produce panels by plasticization and polymerization technique, i.e. by self-adhesion chemical constituents at high temperatures $\left(170,200\right.$ and $\left.230^{\circ} \mathrm{C}\right)$ and long times pressing (20 minutes). Plates with pressing temperature of $230^{\circ} \mathrm{C}$ achieved MOR and MOE values respectively $7.2 \mathrm{~N} / \mathrm{mm}^{2}$ and $1684 \mathrm{~N} / \mathrm{mm}^{2}$, thereby demonstrating the feasibility of using these wastes.

Poleto et a1.[6] produced panels with $100 \%$ Pinus elliottii bark particles and castor oil based polyurethane resin. Good performance was obtained when compared to panel produced under the same conditions, but with only wood in its composition.

In addition to particular features of waste constituents (bark, twigs, etc.), must be considered the species properties used in particleboard production, which will influence the final characteristics of this product.

Genus Hymenaea occurs throughout Brazil and at least thirteen of its species present high commercial value. They are woods with high density and mechanical properties as well as medium to high durability and low natural shrinkage values. Commonly, they're used in manufacture of floors with great value-added[7].

Nectandra lanceolata Nees, commonly known as Canela-A marela or Canelinha, has occurred in the South and Southeast of Brazil, as well as in countries like Argentina and Uruguay. It's characterized by yellowish color and medium density, easy workability and has been used main ly in civil construction (indoor use) and furniture industry[8].

Considering the cited references, it can be observed the relevance of researches aiming to the application the tailings resulting from tree management (such as from pruning) in medium density particleboard production.

\section{Materials and Methods}

Panel production and characterization was preceded in Wood and Timber Structures Laboratory, Structural Engineering Department, São Carlos Engineering School, University of Sao Paulo, Brazil.

Urban tree pruning of Jatobá (Hymenaea stilbocarpa) and Canelinha (Nectandra lanceolata) were used, once performed leaves separation. The remaining material was processed in knife mill with a $2.8 \mathrm{~mm}$ sieve, so obtaining the particles to panel production. Adhesion among particles was reached using castor oil based polyurethane resin (bi-component, consisting of prepolymer and polyol) at a ratio of $16 \%$ (based on wood mass).

Production parameters were based on previous work of Nascimento[9], Dias [10] and Bertolini[11].

Particles and adhesive were homogenized in a special adhesion set (laboratory scale). Mixture was subjected to compression in order to form the mattress and after to hot pressing, as showed in "Figure 1". Press cycle was performed at $90^{\circ} \mathrm{C}$ and pressure of $3.5 \mathrm{MPa}$. Nominal dimensions of the panels were $40 \mathrm{~cm} \mathrm{x} 40 \mathrm{~cm}$ and $10 \mathrm{~mm}$ of thickness.

Six panels were produced for each species and for the two essences mixture, totaling 3 treatments: J-J atobá; C-Canelinha and JC - mix of species. The characterization was performed as required by NBR 14810:3[12]. The following properties were determined: density; moisture content; thickness swelling and water absorption (both in 2 hours); modulus of rupture (MOR) and modulus of elasticity (MOE) in static bending; and internal bond.

Values of each property were analyzed by: ANOVA test; mean comparison by Tukey test, at 95\% probability. Performance of panels was compared to the main regulatory requirements for these products ANSI A208.1[13], CS 236-66[14], NBR 14810:2 [15] and EN 312[16].
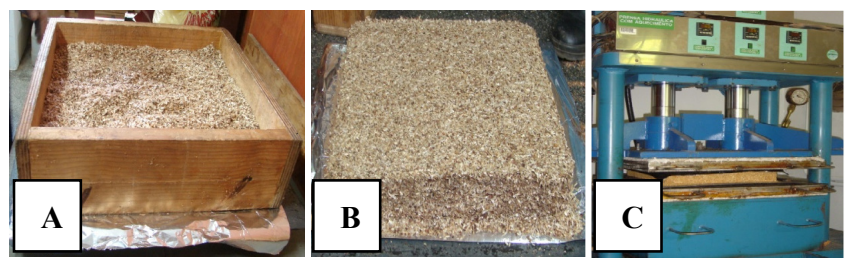

Figure 1. Compression in order to form the mattress (a e b) and hot pressing (c)

\section{Results and Discussion}

Physical properties of panels: density, mo isture content, thickness swelling ( 2 hours) and water absorption ( 2 hours) are presented in Table 1.

Table 1. Particleboard-Physical Properties

\begin{tabular}{|c|c|c|c|c|c|c|c|c|}
\hline \multirow{3}{*}{ Treatment } & \multicolumn{2}{|c|}{$\begin{array}{c}\text { Density } \\
\left(\mathrm{g} / \mathrm{cm}^{3}\right)\end{array}$} & \multicolumn{2}{c|}{$\begin{array}{c}\text { Moisture } \\
\text { Content (\%) }\end{array}$} & \multicolumn{2}{c|}{$\begin{array}{c}\text { Thickness } \\
\text { Swelling - 2 } \\
\text { hours (\%) }\end{array}$} & \multicolumn{2}{c|}{$\begin{array}{c}\text { Water } \\
\text { Absorption - } \\
\text { 2 hours (\%) }\end{array}$} \\
\cline { 2 - 10 } & Mean & VC & Mean & VC & Mean & VC & Mean & VC \\
\hline J & $0.97 \mathrm{a}$ & 0.02 & $6.18 \mathrm{a}$ & 0.06 & $4.95 \mathrm{a}$ & 0.08 & $6.55 \mathrm{a}$ & 0.13 \\
\hline $\mathrm{C}$ & $0.86 \mathrm{c}$ & 0.01 & $5.5 \mathrm{~b}$ & 0.03 & $4.65 \mathrm{a}$ & 0.2 & $7.13 \mathrm{a}$ & 0.13 \\
\hline JC & $0.89 \mathrm{~b}$ & 0.01 & $6.72 \mathrm{a}$ & 0.08 & $5.58 \mathrm{a}$ & 0.12 & $7.22 \mathrm{a}$ & 0.07 \\
\hline
\end{tabular}

Jatobá (J), Canelinha (C) and mixture of species (JC); variation coeffi cient of the means (VC)

Means followed by same letter do not differ from one another in Tukey test at $95 \%$ probability

Panel density values allow classify them as high density $(\geq$ $\left.0.80 \mathrm{~g} / \mathrm{cm}^{3}\right)$, as described in ANSI A208.1[13] and CS 236-66[14].

It is observed that mo isture content of the panels with a mixture of species (JC) was above those samples using only one species ( $\mathrm{J}$ and $\mathrm{C}$ ). Th is may be related to the possibility 
of lower water loss as vapor, during pressing, imposed by mixing particles of two species. Another possibility may be related to the presence of higher percentage of bark particles in JC panels and, consequent, higher moisture content. For this property, just the panels $\mathrm{C}$ showed a statisticald ifference compared to the other treatments.

In cases of thickness swelling and water absorption, both within 2 hours, all treatments presented statistical equivalence. Considering thickness swelling (2 hours) requirement up to $8 \%$, established by NBR 14810:2[15] and ANSI A 208.1[13], all treatments showed up accordingly. Satisfactory values of these properties can be related to the use of materials (as polyurethane resin and bark particles) with high hydrophobicity. In similar studies with castor oil based polyurethane resin presented by Poleto et al.[6], the following results were obtained: $2.3 \%$ in water absorption (2 hours) for panels containing $100 \%$ bark particles of Pinus elliottii and; $8.7 \%$ for panels containing only wood particles of the same species.

Table 2 shows the values obtained for the mechanical properties in static bending and internal bond (in tests perpendicular to panel faces).

Table 2. Particleboards - MechanicalProperties

\begin{tabular}{|c|c|c|c|c|c|c|}
\hline \multirow{2}{*}{ Treatment } & \multicolumn{2}{|c|}{ MOR (MPa) } & \multicolumn{2}{|c|}{ MOE (MPa) } & \multicolumn{2}{|c|}{ IB (MPa) } \\
\cline { 2 - 7 } & Média & CV & Média & CV & Média & CV \\
\hline J & $17.30 \mathrm{a}$ & 0.07 & $1773 \mathrm{a}$ & 0.09 & $1.00 \mathrm{a}$ & 0.08 \\
\hline $\mathrm{C}$ & $15.85 \mathrm{a}$ & 0.04 & $1642 \mathrm{a}$ & 0.05 & $0.80 \mathrm{~b}$ & 0.08 \\
\hline $\mathrm{JC}$ & $16.8 \mathrm{a}$ & 0.07 & $1619 \mathrm{a}$ & 0.06 & $0.82 \mathrm{~b}$ & 0.10 \\
\hline
\end{tabular}

Jatobá (J), Canelinha (C) and mixture of species (JC); variation coefficient of the means (VC); IB - internal bond.

Means followed by same letter do not differ from one another in Tukey test at $95 \%$ probability.

Regarding the MOR, treatments with mixed species (JC) and Jatobá particles $(\mathrm{J})$ showed superior performance to $16 \mathrm{~N} / \mathrm{mm}^{2}$, as required by EN $312[16] ; 16.5 \mathrm{~N} / \mathrm{mm}^{2}$, as required by ANSI A 208.1[13]; and $168 \mathrm{~kg} / \mathrm{cm}^{2}$, as required by CS 236-66[14]. For MOE, all treatments were not in accordance with referenced Codes. Alltreatments showed no statistical difference between static bending properties.

Considering internal bond, it is observed that all samples were above the $0.4 \mathrm{~N} / \mathrm{mm}^{2}$ (or $0.4 \mathrm{MPa}$ ), required by NBR 14810:2[15] and EN 312[16]. Only particleboards made of Jatobá (J) performed better than the $0.90 \mathrm{~N} / \mathrm{mm}^{2}$, as stipulated by ANSI A 208.1[13]. Jatobá panels showed superior results to other species and mix, as evidenced by statistical analysis.

Usually, low to medium density wood species are employed to panel production[17], such as Canelinha (0.70 $\mathrm{g} / \mathrm{cm}^{3}$ ) used in this work, to obtain efficient compression and interaction particles-adhesive. Although a high density essence, Jatobá $\left(0.96 \mathrm{~g} / \mathrm{cm}^{3}\right)$ has been also used, a superior performance in internal bond was observed comparing to panels produced with lowest density species.

Nascimento[9] produced MDP with native species from northeastern Brazil, as Jurema Preta (Mimosa tenuiflora), Algaroba (Prosopis juliflora) and Angico (Anadenanthera macrocarpa), density ranging from 0.95 to $1.04 \mathrm{~g} / \mathrm{cm}^{3}$. High values of internal adhesion were obtained to these products: $2 \mathrm{MPa} ; 1.7 \mathrm{MPa}$ and $1.6 \mathrm{MPa}$, respectively. This clearly shows the potential of employing high-density essences for MDP production purpose.

\section{Conclusions}

Considering the obtained results, it is possible to point out these conclusions:

- All produced panels can be classified as high density MDP;

- Hydrophobic nature of adhesive and bark particles collaborate to obtaining low values of water absorption and thickness swelling (both within 2 hours);

- Partic leboards of Jatobá particles and those with mix species showed high static bending performance (MOR);

- All treatments conduced to high values of internal bond (in tests perpendicular to panel faces), exceeding codes requirements, and highlighted the superiority of Jatobá panels.

All results in this paper demonstrate the possibility of employing particles obtained from pruning high density urban trees, including their bark in the production of MDP.

\section{ACKNOWLEDGEMENTS}

To "Pro-Rectory of Culture and University Extension" University of São Paulo (USP); São Paulo Research Foundation (FAPESP), by financial support; and Plural Chemical Industry LTDA., by furnishing adhesive employed in laboratory tests.

\section{REFERENCES}

[1] Sajdak Magdalena. Velázquez-Martí Borja. Estimation of pruned biomass form dendrometric parameters on urban forests: Case study of Sophora japonica. Renewable Energy, vol. 47, pp.188-193, 2012.

[2] FAO. FAOSTAT Forestry. 2010. Online Available: http://faostat.fao.org/site/626/DesktopDefault.aspx?PageID= 626\#ancor.

[3] Peredo Miguel L. Inclusion de biomasa forestal en la fabricacion de tableros de particulas. Bosque, vol. 7, no. 1, pp. 9-16, 1986.

[4] Iwakiri Setsuo. Cruz Clair Rogério. Olandoski Danièlle Previdi. Brand Marta Andréia. Utilização de resíduos de serraria na produção de chapas de madeira aglomerada de Eucalyptus saligna, Eucalyptus citriodora e Eucalyptus pilularis. Revista Floresta e Ambiente, v. 7, n. 1, p. $251-$ 256. Universidade Federal Rural do Rio de Janeiro. Rio de Janeiro - RJ. 2000.

[5] Gupta Gireesh Kumar. Development of bark-based environmental-friendly composite panels, Master of Science 
in Forestry, Dissertation, University of Toronto, USA, 2009.

[6] Poleto Sabrina Fernanda Sartório. Bertolini Marília Silva. Nascimento Maria Fátima. Rocco Lahr Francisco Antonio. "Influence of bark residues of Pinus elliottii addition on physical and mechanical properties of particleboards" in: Proceedings of I Pro-Africa. Pirassununga, SP : FZEA-USP, 2010. v. 1.

[7] Mainieri Calvino. João Peres Chimelo. Fichas características das madeiras do Brasil. Ficha de caracterísiticas das madeiras brasileiras. São Paulo: Instituto de Pesquisas Tecnológicas, 1989.

[8] Brack Paulo. Grings Martin. Kinupp Valdely. Lisboa Gustavo. Barros Ingrid. Espécies Arbóreas de Uso Estratégico para Agricultura Familiar. 2011. Online Available:< www.ufrgs.br/viveiroscomunitarios/publicaco es/ESPECIES ARBOREAS DE USO ESTRATEGICO PARA AGRICULTURA FAMILIAR .pdf $>$.

[9] Nascimento Maria Fátima. CPH - Chapas de Partículas Homogêneas: madeiras do nordeste do Brasil. $\mathrm{PhD}$. in Science and Materials Engineering, Thesis, University of São Paulo, São Carlos, 2003.

[10] Dias Fabrício Moura. Aplicação de resina poliuretana à base de mamona na fabricação de painéis de madeira aglomerada. Produtos derivados da madeira: síntese dos trabalhos desenvolvidos no Laboratório de Madeiras e de Estruturas de Madeira, SET-EESC-USP. São Carlos: Escola de En genharia de São Carlos, Universidade de São Paulo. p. 73-92, 2008.

[11] Bertolini Marilia Silva. Emprego de resíduos de Pinus sp. tratado com preservante CCB na produção de chapas de partículas homogêneas utilizando resina poliuretana à base de mamona. Master in Science and Materials Engineering, Dissertation, University of São Paulo, São Carlos, 2011.

[12] Associação Brasileira de Normas Técnicas. NBR 14810: Chapas de madeira aglomerada. Parte 3: Métodos de Ensaio. Rio de Janeiro. 2006.

[13] American National Standard. A208.1: Particleboard. Gaithersburg. 1999.

[14] Commercial Standard. CS 236-66: Mat formed wood particleboard, 1968.

[15] Associação Brasileira de Normas Técnicas. NBR 14810: Chapas de madeira aglomerada. Parte 2: Requisitos. Rio de Janeiro. 2006.

[16] European Standard. EN 312: Particleboards - Specifications. British Standard. English version. Brussels. 2003.

[17] Moslemi, Ali A. Particleboard. London: Southern Illino is University Press, 1974. 